\title{
Lateral soil pressure induced failures
}

\author{
T.A. Ooi ${ }^{\text {i) }}$ C.H. Tee ${ }^{\text {ii) }}$ and C.B. Chan ${ }^{\text {iii) }}$ \\ i) TAO Consult Sdn Bhd, Malaysia. \\ ii) \& iii) Mega Geoproducts And Services Sdn Bhd, Malaysia.
}

\begin{abstract}
In early 1970s in Malaysia many piled bridge abutments on soft ground experienced failures during earth embankment construction. The Public Works Department (PWD) issued a directive to construct the earth embankment first with surcharge load before the piled bridge abutment was built. This simple procedure and precaution eliminated the incidences of bridge abutment failures for at least 10 years. In 1980s a bridge abutment failed again with an embankment height of $7 \mathrm{~m}$ under similar soft ground conditions when the PWD directive was not followed. The concept of construction of the embankment first was principally to eliminate significant settlement and lateral movement of the soft ground before the construction of the piled bridge abutment. Damages to piles and foundation can occur as a result of lateral soil pressure and soil movements. This aspect of risk and mitigation of failure has often time been ignored by the designer and supervising engineer alike. In 1993 the 12-storey Block 1 Highland Towers collapse was also due to the lateral soil pressure exerted by the culmination of falling earth fill from retrogressive landslides behind the building causing the old used rail piles that was used as building foundation to yield and sheared off. This paper examines some recent cases of failures due to lateral soil pressure and their rehabilitation. Vacuum consolidation offers good remedial solution to unstable ground with bridge abutment.
\end{abstract}

Keywords: Case histories, Lateral pressure, Soil movement, Rehabilitation

\section{INTRODUCTION}

In the early 1970s there were several bridges in the Kota Tinggi district where the $5-6 \mathrm{~m}$ earth fill embankments behind the bridge abutments failed and bodily moved the bridge abutments and the piles with them during construction. At about the same time the $12 \mathrm{~m}$ high embankment behind the new Temerloh Bridge abutment on the Temerloh side also failed during construction damaging the piles, tilting the abutment and at the same time damaging and tilting the pier immediately in front of it. The piles, abutment and pier were constructed prior to the embankment construction. The embankments were located over clay layers. All the affected abutments and pier had to be demolished and new piles, abutments and pier were constructed. Fig. 1 shows the embankment failure at the Temerloh bridge abutment. Consequent to these incidences, a KPKR (Director-General of PWD) Circular was issued directing that embankments within $50 \mathrm{~m}$ of the bridge abutment must be constructed to their full height first before piling for the bridge abutments can commenced. The stability of embankment must be designed for the abutment with suitable counterbalancing berms and suitable ground improvement technique employed.
The implementation of this precaution and procedure appeared to put an end to the spate of embankments and abutment failures. However, in the mid-1980s, a bridge abutment in Selangor also suffered the same fate. In that case, construction of the $8 \mathrm{~m}$ high embankment started after the piled foundation and abutment were constructed. During building up of the embankment and at about $7 \mathrm{~m}$ high, the embankment moved by about $1.12 \mathrm{~m}$ in predominantly horizontal direction towards the river. There were no instrumentation to monitor the construction of the embankment in soft clay and there was also no slope stability check on the embankment and the abutment in the direction towards the river.

The failure could have been easily avoided had the embankment at the bridge abutment area be constructed first before piling and abutment construction. Any ground improvement required could also have be undertaken during the embankment construction prior to the construction of the bridge abutment. Clearly, this particular case ought never to have happened if the proper precautions and procedure had been adopted.

Ting et al., (1995) reported the use of vacuum consolidation at a bridge abutment where the strength of the soft ground had to be improved after the construction of the abutment structure. 

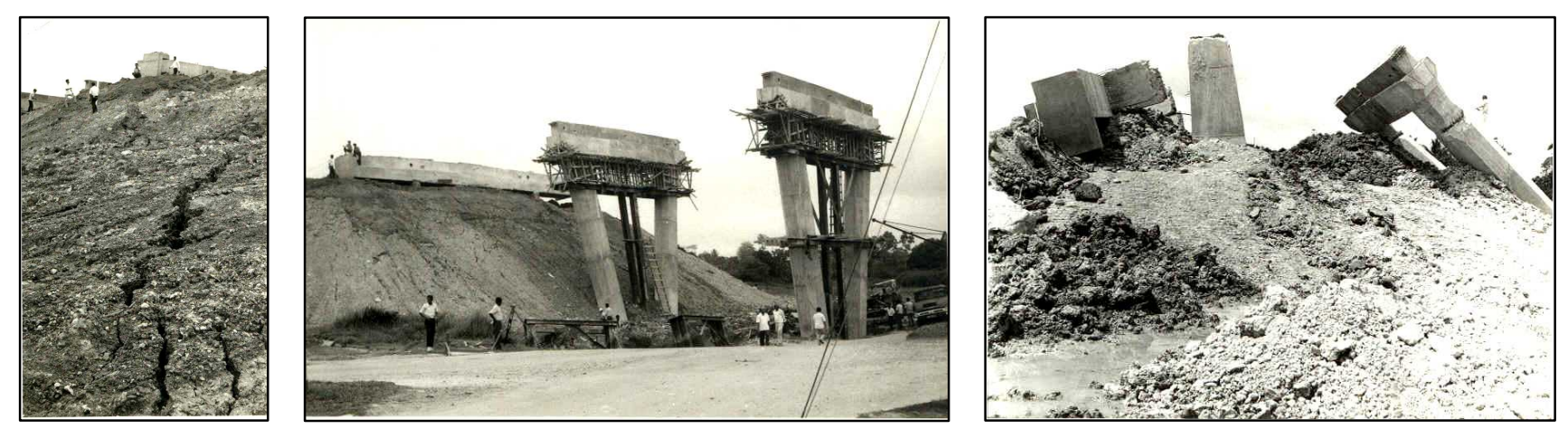

Fig. 1 Abutment failure Temerloh bridge (after Ooi \& Ooi, 2009).

Vacuum consolidation was applied to the ground to increase the soil strength successfully without causing instability to the completed structures. The embankment was successfully constructed after vacuum consolidation, thus avoided a potential danger of an abutment failure during construction. It must be pointed out that vacuum consolidation is an isotropic consolidation thus causing no deviator stress and lateral load on piles.

Tan (1988) examined the lateral load on piled abutment of bridge approach embankment and concluded that conventional method of bridge abutment design does not consider the possible lateral load on pile due to asymmetric surcharge loading. It was suggested that preliminary check on abutment movement should be made and if found significant steps should be taken to remedy the situation. For very high embankment in soft ground piled embankment has been used successfully (Chin, 1985; Ooi et al, 1987).

In late 1983 a slope failure approximately $30 \mathrm{~m}$ high and $25 \mathrm{~m}$ wide occurred at Motel Desa, Kuala Trengganu during the monsoon season. Slope reconstruction involved construction of a $6.7 \mathrm{~m}$ high Geogrid reinforced slope supported on a concrete platform on micropile of 50 ton capacity at mid-slope. The designer was mindful of the lateral load on piles at mid slope and raked steel pipe pile of API was used to take care of the lateral load. Below the Geogrid reinforced slope and surrounding unreinforced fill slope was used at a gentle slope of about 26 degree. The reinforced slope and surrounding unreinforced slopes were instrumented using inclinometers, strain gauges, piezometers, pressure cells and settlement stations. This work was reported by Toh et al (1986). It was found that unreinforced compacted slope moved as much as $70 \mathrm{~mm}$ as indicated by the inclinometer with a settlement of $200 \mathrm{~mm}$. Small concrete piles would be damaged with this magnitude of lateral movement.

In December1993, block 1 of three blocks of 12 storey high luxurious condominiums collapsed when the slope failed retrogressively behind the building. The successive failure of slope imposing a high lateral load on piles due to piling up of earth behind the building causing the rail piles to shear off and the building to collapsed. Fig. 2 shows the retrogressive slope failures.

This paper reports some incidence of pile failures due to lateral load in Malaysia and the rehabilitation works.

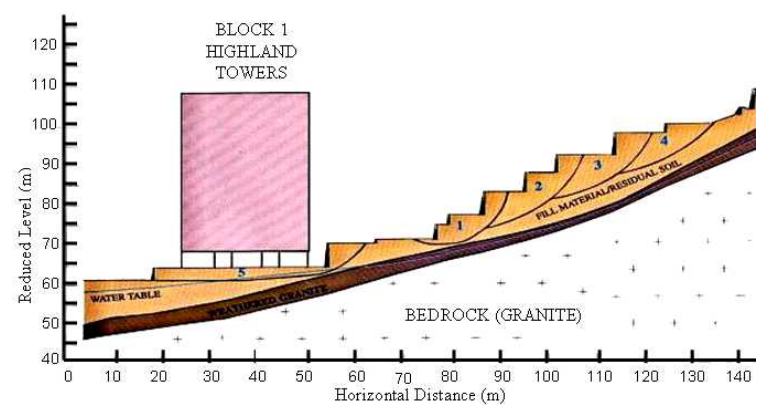

Fig. 2 Highland Tower retrogressive landslide failures (after Ooi \& Ooi, 2009).

\section{SHAH ALAM BRIDGE}

In the case of Shan Alam Bridge piled abutment supported by the precast reinforced concrete driven piles were constructed first before any ground improvement works were carried out. Filling of the embankment at the abutment started straight away upon completion of piling and the bank seat for the bridge beams. The design height of the embankment at the abutment was $8 \mathrm{~m}$. On reaching the fill height of $7 \mathrm{~m}$ failure occurred with the embankment moving $1.12 \mathrm{~m}$ towards the river. There were no stability analysis of the embankment at the bridge abutment before construction nor were there any construction method statement from the contractor. The rehabilitation of the abutment failure was the innovative use of a geogrid reinforced embankment supported on concrete tripile with pilecaps connected by tie beam as shown in Fig. 3 . At behind the bridge abutment, a gap was provided to eliminate any lateral load on the existing abutment underpinned by API steel pipe micropiles. This method of relieving the lateral pressure was further improved in new abutment design where the bank seat is bearing directly on the pile supported geogrid reinforced block with Keystone Block facing. 


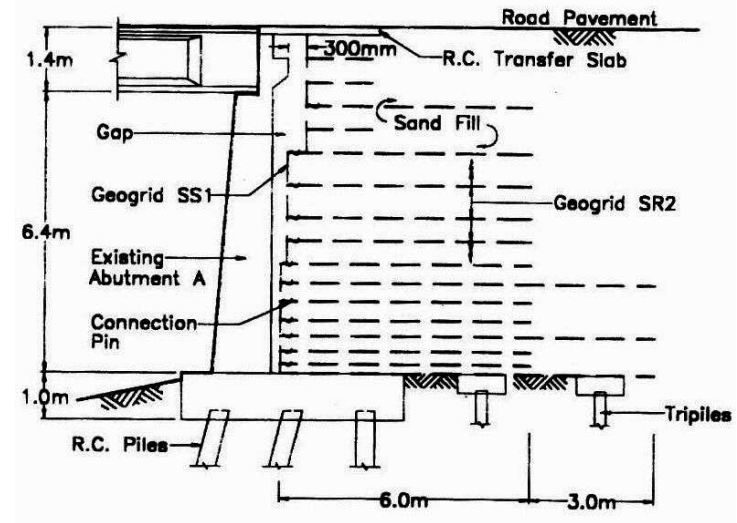

Fig. 3 Shah Alam bridge rehabilitation (after Chan, 2000).
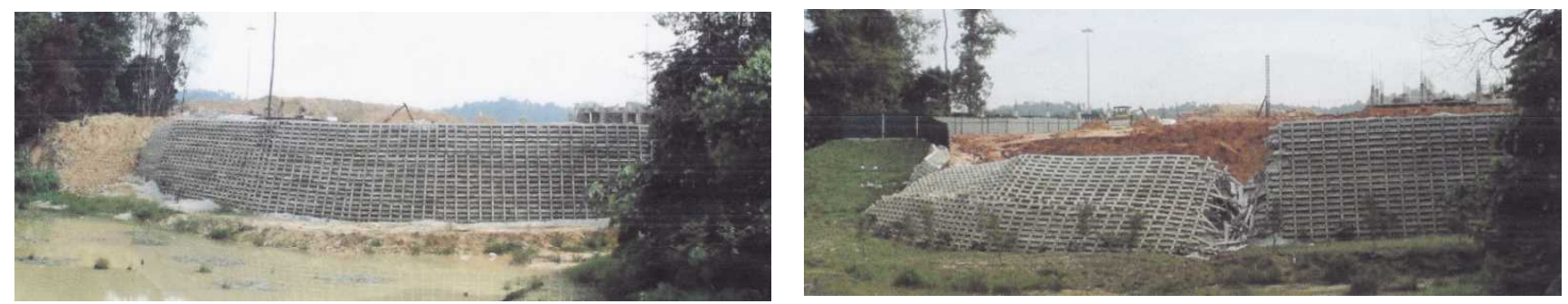

Fig. 4: Cribwall before and after failure.

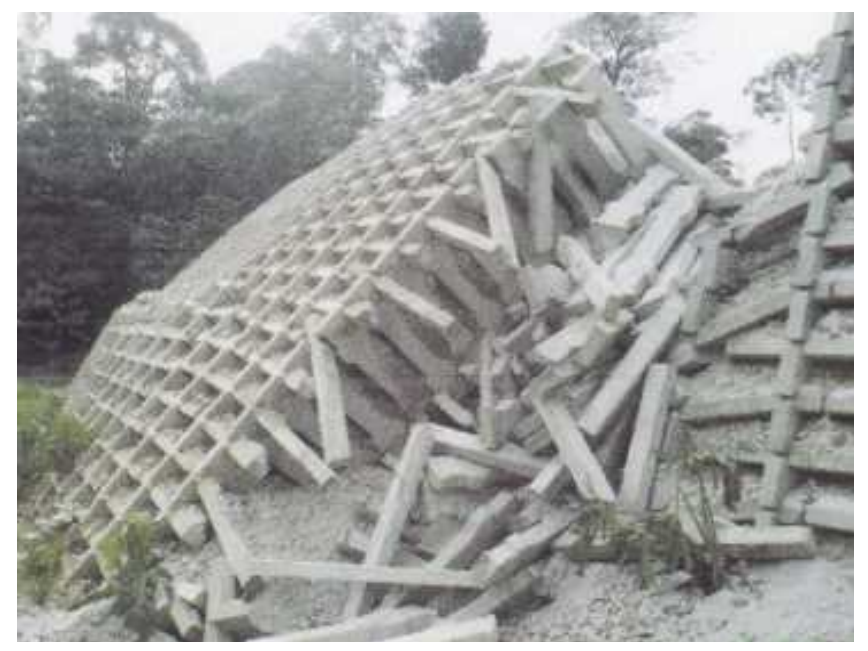

(a)

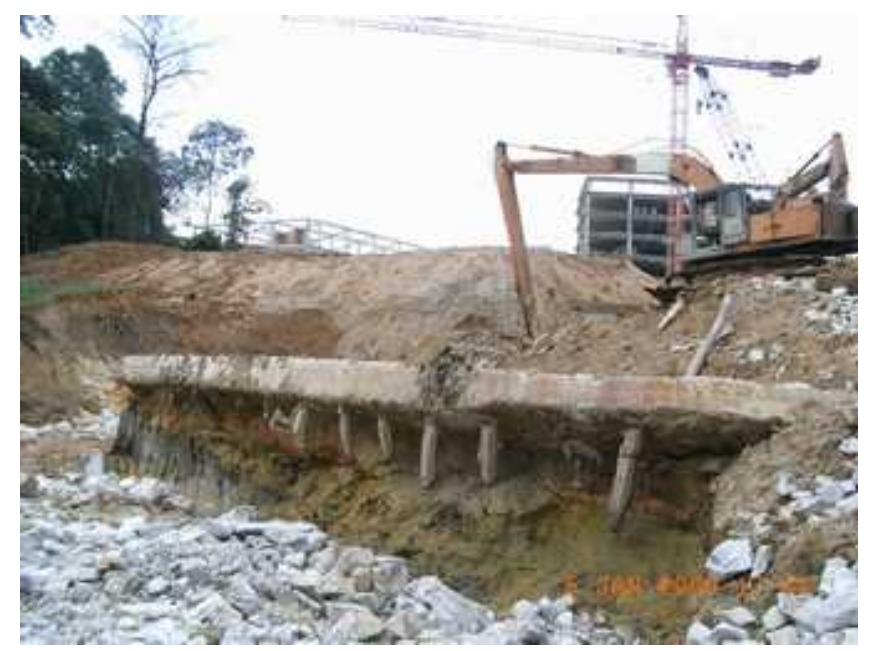

(b)

Fig. 5 Failure of Cribwall after ground movement resulted in broken piles.

\subsection{Design Concept of Rehabilitation Works}

Site investigation carried out after failure shows that there exist a soft layer of approximately $5 \mathrm{~m}$ thick below the pond that has to be removed and replaced by rockfill in order to provide a stable base for the

\section{KOTA DAMANSARA CRIBWALL}

A sports complex with commercial building development at Kota Damansara has an $8 \mathrm{~m}$ high crib-wall founded on R.C. piled foundation was constructed at the edge of a partially filled pond. Failure occurred during construction and resulted in

i) A partially completed cribwall collapsed towards the pond as shown in Fig. 4.

ii) Ground movement at toe caused collapse of the cribwall as shown in Fig. 5a.

iii) Broken $175 \mathrm{~mm} \times 175 \mathrm{~mm}$ R.C. piles that supported the crib wall as shown in Fig. 5b.

iv) Construction of commercial buildings on top of the cribwall was put on hold. 


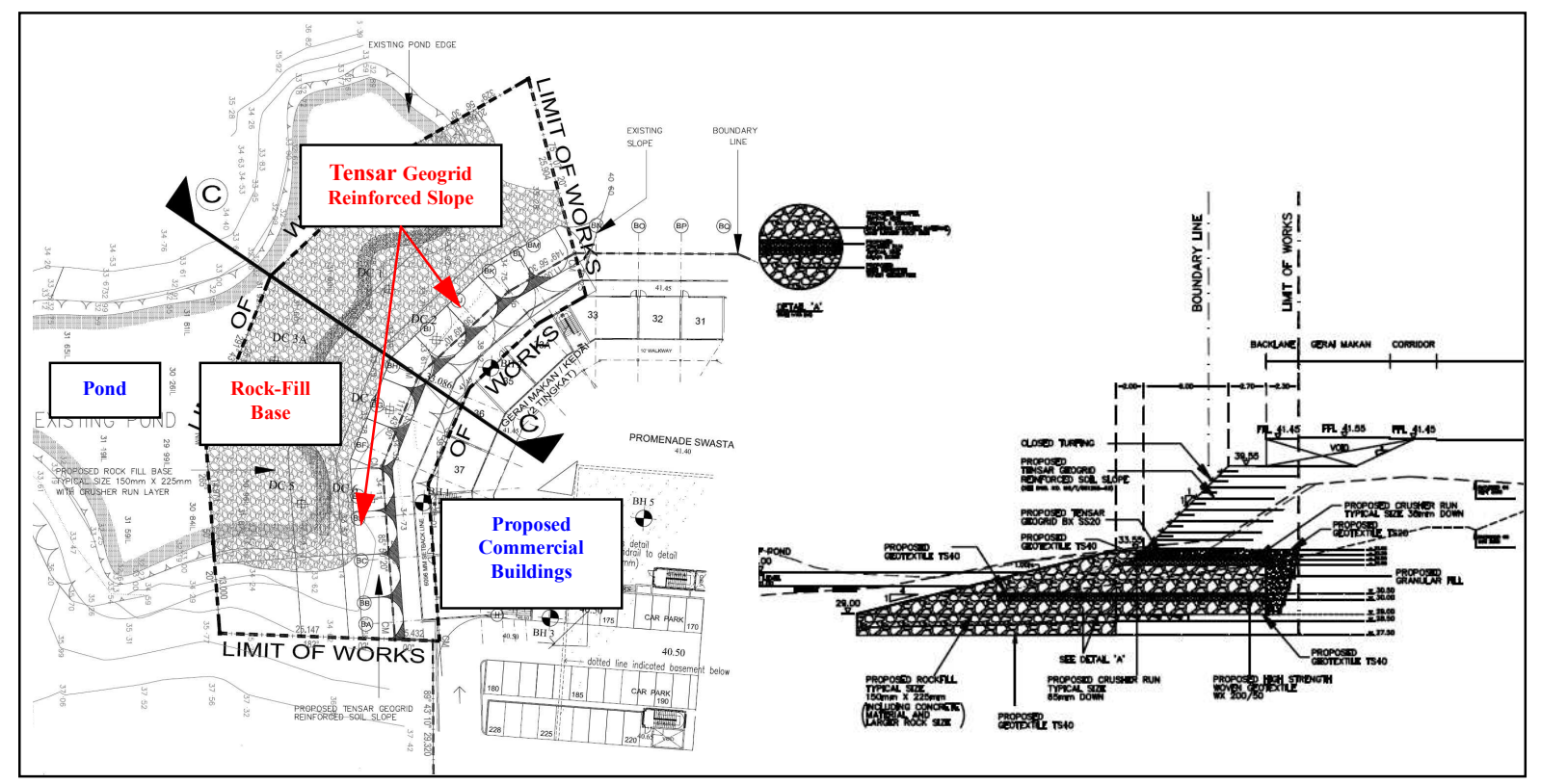

Fig. 6 Geogrid Remedial Work Scheme.

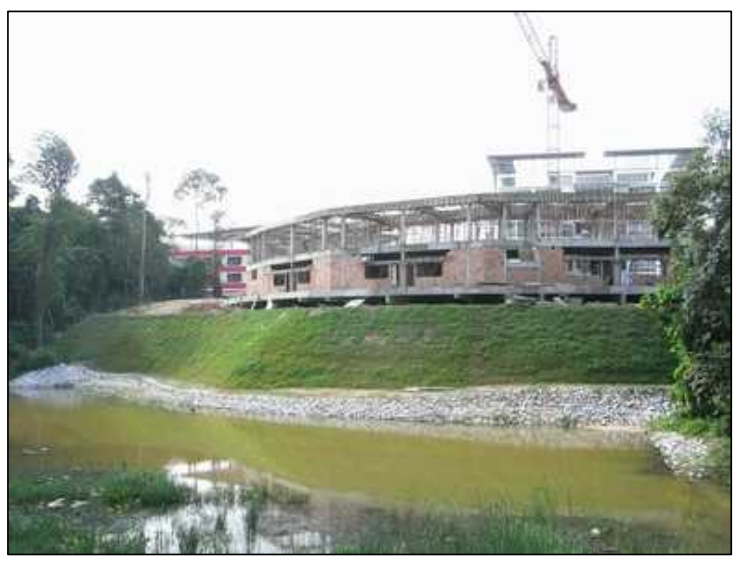

Fig. 7 Completed remedial work with construction of commercial building.

\section{TAMAN ZOOVIEW LANDSLIDE}

On $31^{\text {st }}$ May 2006, Landslide occurred at the back of a row of double storey terrace houses located on top of the slope of Taman Zooview. In the incidence, the following damages were reported to have incurred:

a) A newly constructed Anchored Soil Wall of $6 \mathrm{~m}$ high and $40 \mathrm{~m}$ long located at the boundary of the development to Taman Zooview collapsed and moved about $100 \mathrm{~m}$ down the slope.

b) Extensive ground movement on the down slope side of the wall resulting in the destruction of three long houses at the bottom of the slope and loss of four lives.

c) The fifteen (15) units of terrace houses located on top of the slope in Taman Zooview were subject to evacuation order by the local authority as these houses were considered unsafe for occupation.

\subsection{Tip-fill slope}

The fifteen (15) units of terrace houses located on top of the slope were constructed on fill of over $13 \mathrm{~m}$ thick over a ravine with loose tip-fill slope at their backyard that was constantly slipping over the last 20 years since the houses were built. The drainage system has since not been functioning. To make matter worst, the residents have taken upon themselves to indiscriminately discharge domestic and storm water over the slope from their houses. According to the house owners, the fill-slope at the backyard has been eroding and slipping since completion and has become critical when the edge of the slope came close to the houses. Water from the gutters of the houses was connected by plastic pipes to discharge further down the slope. Slope stability analysis shows that the factor of safety for localized slope failure to be 1.05 . The slope is thus perching precariously and failure can be expected to happen at any time, particularly with incessant rainfall and poor drainage system.

\subsection{The reinforced soil wall}

The unstable slope was left as playground in the proposed new development below the boundary of Zooview houses. When the residents of the terrace houses complained to the local authority on the slope movement, a site meeting was held at which the local authority directed the new developer to stabilize the unstable slope with a $40 \mathrm{~m}$ long $\times 6 \mathrm{~m}$ high reinforced soil (RS) wall. The RS wall was built on top of a reinforced concrete slab supported on $\mathrm{RC}$ piles at the boundary by a specialist contractor. According to the global stability analysis submitted by the specialist, the wall has a factor of safety greater than 1.4. The design 
was reviewed and approved by the independent reviewer appointed by the local authority. The drainage condition of the slope remained the same at the time the wall was built. The local authority wanted to complete the wall urgently for fear of the raining season, the construction of the wall took about 6 weeks to reach its full height. The slope behind the terrace houses and the wall collapsed on $31^{\text {st }}$ May 2006, 10 days after the wall

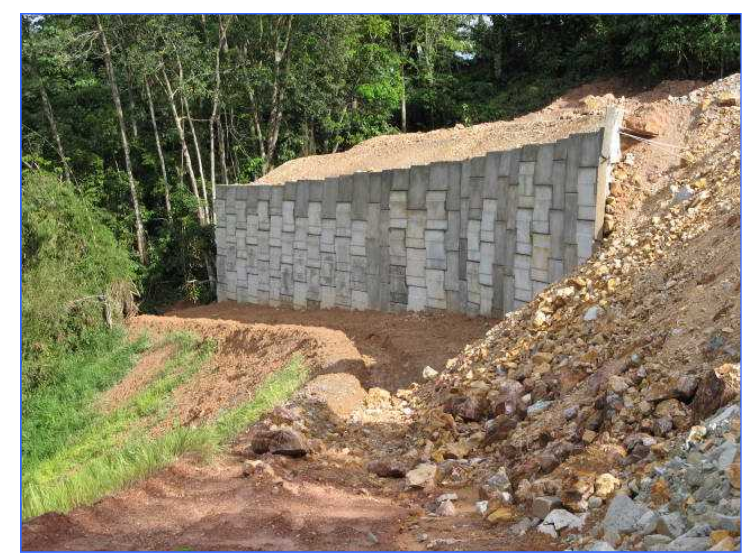

Fig. 8a Completed Anchored Soil Wall.

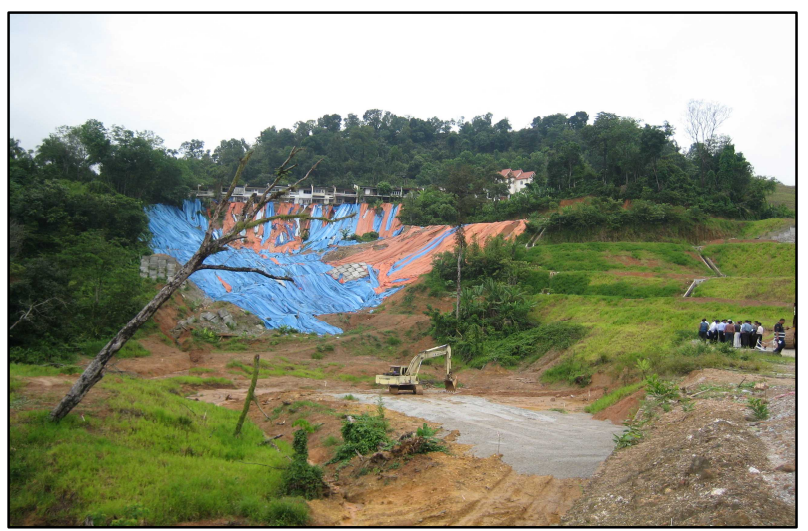

reached its full height of $6 \mathrm{~m}$. The landslide material flowed down the slope and caused massive upheaval of the ground below the slope resulting in the destruction of squatter houses and death of 4 persons. Fig. 8a shows the RS wall on completion. Fig. 8b shows the collapse of the RS wall. Fig. 9 shows the general view of the slope after landslide.

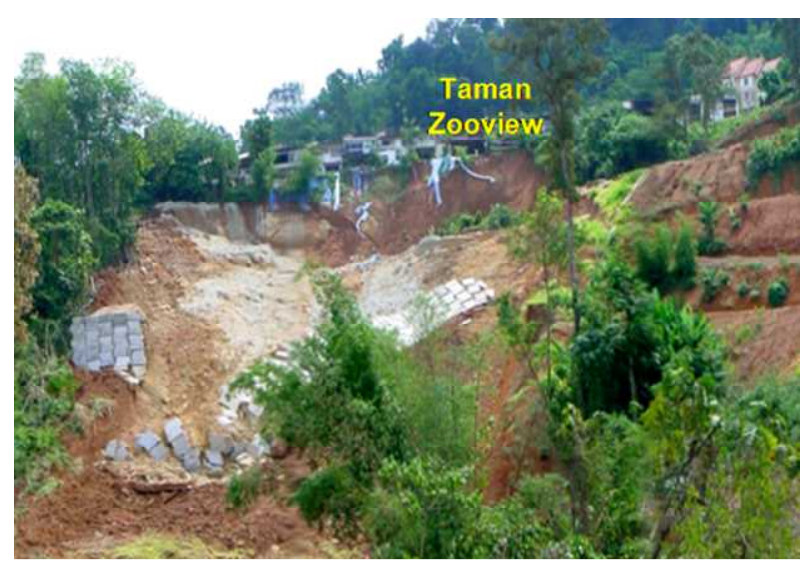

Fig. 8b Reinforced Soil Wall Collapsed.

\subsection{Concept of rehabilitation design}

The site was waterlogged at the bottom of the landslide. Spring water could be seen flowing steadily out of the slope. It was important to drain out all the water with suitable subsoil drainage system and the water led away by gravity flow.

A rock toe embankment with key was provided at a safe distance as shown in Fig. 10. The rock-key was taken down to firm layer of weathered granite at RL $64 \mathrm{~m}$. Subsoil drainage pipes were provided to take the underground water away to the open drain.

Fig. 9 Genral view of Landslide.

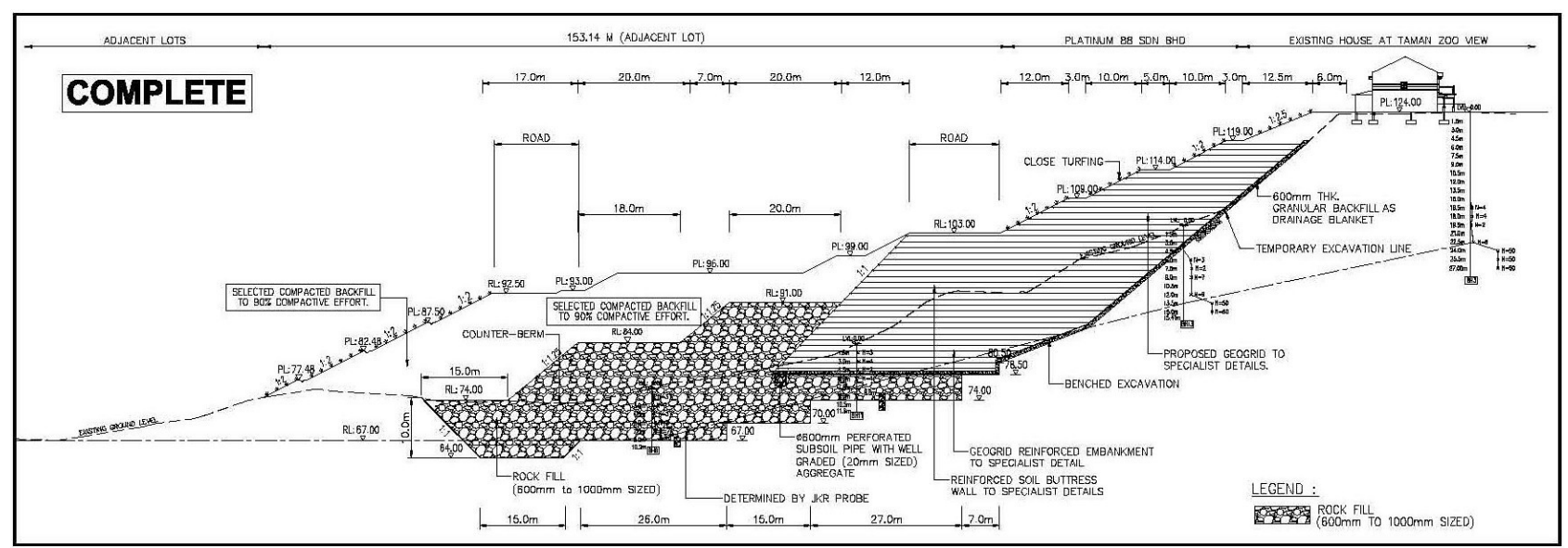

Fig. 10 Typical cross section (after Ooi, 2008). 
It was found that above the firm layer of weathered granite there was a layer of soft organic material of about $1 \mathrm{~m}$ thick. This layer is believed to be the sliding surface at the lower part of the slope that was responsible for the upheaval of the ground indicated by the tilting tree shown in Fig. 9. This layer was completely removed. The construction was therefore divided into 5 stages of excavation and at each stage, slope stability analysis carried out to ensure safe construction. Inclinometers on slope and tell-tale glasses on cracks of the existing terrace houses were installed to monitor the slope movement.

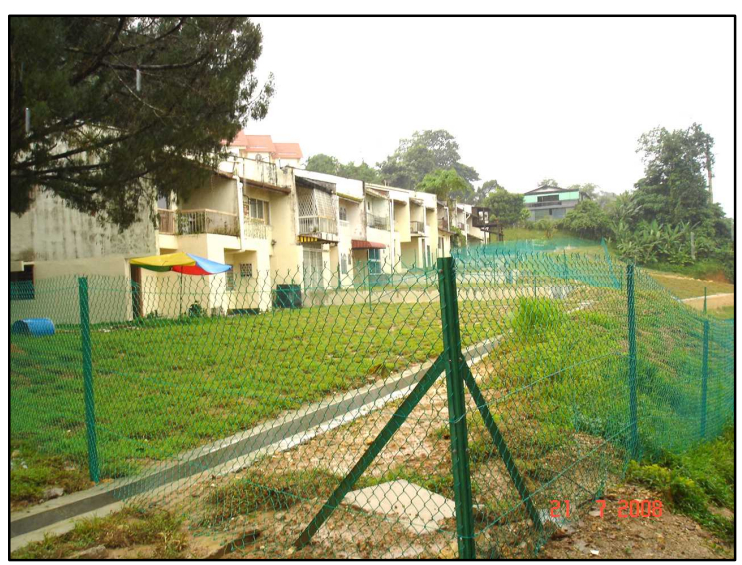

Fig. 11 Back of occupied houses (after Ooi, 2008).

\section{CONCLUSIONS}

The paper has presented cases of failures of piled structures due to lateral pressure/forces on piles. This often happened to bridge abutment supported on piles subject to lateral movements or unbalanced horizontal pressure or forces. The paper also presented two cases of rehabilitation works and improvements to new design of abutment approaches. There are many new instances of piled bridge abutment failures which are subject of court cases currently in progress. Failure to recognize and carry out appropriate slope stability analyses of possible mode of instability involving the bridge abutment either during construction, during service life and as a result of unbalanced forces generated during temporary works can lead to disastrous consequences as in the case of surcharge loading caused by an excavation in placing the excavated earth on one side of bridge abutment that caused instability to occur. Vacuum Consolidation offers good remedial solution in the event of unknowingly constructing the bridge abutment structure prior to ground improvement works.

\section{REFERENCES}

1) Chin F. K. (1985) "The Design and Construction of High Embankments on soft Clays" Special Lecture Eight Southeast Asia Geotechnical Conference Kuala Lumpur.
The reduced level for this excavation is $78.5 \mathrm{~m}$. At this level the second embankment starts with Tensar geogrid reinforcement that was chosen based on its rigidity, integrity and strength at the junctions of the geogrids as well as its ability to mobilize its strength at compatible low strain level of the soil. Fig. 11 shows the completed rehabilitated slope at the back of the house. Note the spacious back garden in contrast with the hanging garden before rehabilitation. Fig. 12 shows the completed $60 \mathrm{~m}$ high slope as view from the bottom of the slope

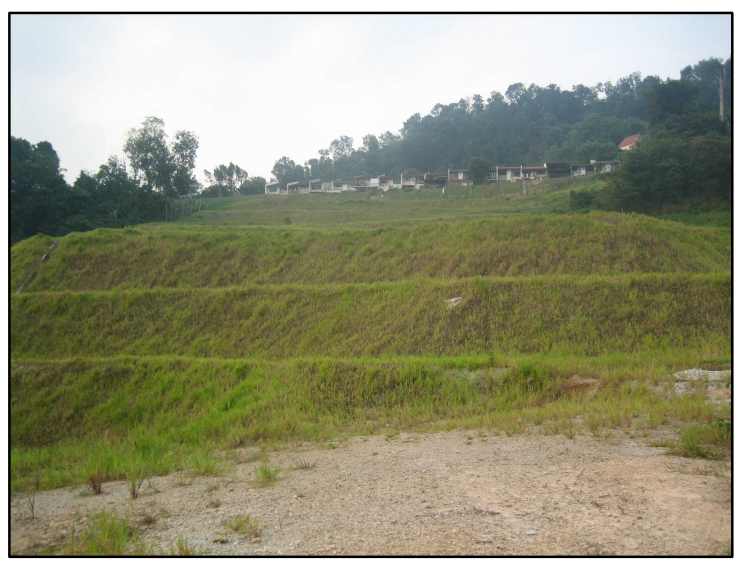

Fig. 12 View of rehabilitated slope (after Ooi, 2008).

2) Ooi T. A. (2008) "Some Aspects of the Mitigations and Rehabilitations of Natural Disasters in Malaysia" Keynote and Special Invited Plenary Lectures, Proceedings 2nd International Conference GEDMAR08, Nanjing, China, pp116-133.

3) Ooi, T. A. Chan, S. F. \& Wong, S. N. (1987). Design, Construction and Performance of Pile Supported Embankments. Proceedings 9th Southeast Asian Conf. on Geotechnical Engineering, Bangkok. Vol. $1.1, \mathrm{pp} 2-1$ to $2-12$.

4) Ooi T.A. and Ooi, H.M. (2010) "Geotechnical Failures/Issues, Dispute Resolution and Mitigation.” 19th Prof. Chin Fung Kee Lecture Nov. 2009, IEM Journal, vol. 71, No.1 Mar. Kuala Lumpur 1-28.

5) Tan Y. K. (1988) "Abutment Failures associated with Approach Embankments on Soft Clay" Proceedings Sarawak Geotechnical Symposium, Kuching, Sarawak.

6) Ting, W.H., Varaksin, S., Tan, K.P. and Spaulding, C. (1995). "Vacuum Consolidation and Dynamic Replacement Columns for Embankment Foundation on Mining Slimes." Proceeding 10th Asian Regional Conference on Soil Mechanics and Foundation Engineering, Beijing, Vol 1, p.453-456.

7) Toh C. T., Chee S. K. and Ting W. H. (1986) "Design, Construction and Performance of a Geogrid Reinforced High Slope and Unreinforced Fill Slopes" IEM - JSSMFE Joint Symposium on Geotechnical Problems, 27-28 March 1986, Kuala Lumpur, 90-111. 